\title{
$A B O$ and Rhesus Blood Group Distribution and Blood Donation Willingness Among First-Year Health Students in a Saudi University
}

\author{
Nouf A AIShamlan (DD \\ Malak A Al Shammari (D) \\ Reem S AIOmar ID \\ Danya Gari \\ Assim M AlAbdulKader (D) \\ Sameerah Motabgani \\ Abdulaziz Farea \\ Magdy A Darwish
}

Department of Family and Community Medicine, Imam Abdulrahman Bin Faisal University, Dammam, Saudi Arabia
Correspondence: Nouf A AIShamlan Department of Family and Community Medicine, Imam Abdulrahman Bin Faisal University, Dammam, Saudi Arabia Tel +966504901406

Email nashamlan@iau.edu.sa
Background: Understanding the distribution of blood groups and blood donation willingness in a population is crucial in managing blood banks and transfusion services. Moreover, awareness of one's own blood group is essential especially in emergencies that mandate blood donation. This study aimed to determine the distribution of ABO and Rhesus $(\mathrm{Rh})$ blood groups among health students, the students' knowledge about their blood group, and their willingness to donate blood.

Methods: This cross-sectional study included all newly accepted health students in a large university in the Eastern Province of Saudi Arabia ( $N=1145)$ during August 2020. The data included a self-administered questionnaire and the serology results of $\mathrm{ABO}$ and $\mathrm{Rh}$ factors. Chi-squared and Fisher's exact tests were performed followed by a multivariable binary logistic regression analysis which identified the predictors of willingness of blood donation. Results: Blood group O was the most frequent type among students $(51.1 \%)$, followed by group A (24.5\%) and B (20.4\%). The majority (93.3\%) of students had Rh-positive factor. When we compared students' answers with their sample results, most students $(75.5 \%)$ correctly reported their $\mathrm{ABO}$ and $\mathrm{Rh}$ blood groups. Male students and those with a previous history of blood donation correctly reported their blood group more than others. Of the total sample, $47.3 \%$ were willing to donate blood within the next year. Positive predictors of the willingness of student to donate blood included being male, and those with a history of blood donation. Interestingly, students with a family member in the healthcare field were significantly less likely to donate blood.

Conclusion: Blood group $\mathrm{O}$ and $\mathrm{Rh}$ positive were the most frequent blood groups. Most students had a good knowledge about their blood groups, and about half of students were willing to donate blood. Efforts to encourage the young population to participate in blood donation are crucial.

Keywords: ABO blood group, Rh factor, blood donation, Saudi, students

\section{Introduction}

$\mathrm{ABO}$ and Rhesus (Rh) blood groups, the most recognized blood group systems, are important for transfusion and transplantation safety, and have been linked with susceptibility to certain diseases. ${ }^{1}$ Frequencies of blood groups vary in different ethnic groups. In the United States, among Caucasians, the distribution of blood groups $\mathrm{O}, \mathrm{A}, \mathrm{B}$, and $\mathrm{AB}$ was $45.0 \%, 40.0 \%, 11.0 \%$, and $4.0 \%$, respectively. In Hispanics, the frequencies were reported to be $57.0 \%, 31.0 \%, 10.0 \%$ and $3.0 \%$, respectively. In Blacks, the distributions were $50.0 \%, 26.0 \%, 20.0 \%$ and $4.0 \%$, 
respectively. ${ }^{2}$ In China, the most common blood group was A (30.5\%), followed by $\mathrm{O}(30.4 \%)$ and B (29.4\%), and the least common was AB (9.7\%). Moreover, only $1.02 \%$ of the population had Rh-negative factor. ${ }^{1}$ In Saudi Arabia, a previous report among 9939 stem cell donors from different regions in the Kingdom showed that Blood group $\mathrm{O}$ was the most frequent type $(50.4 \%)$, followed by group A (28.6\%), and B (17.1\%), and the least common was group $\mathrm{AB}$ (4.0\%), Moreover, about $90.0 \%$ of donors were Rh-positive. ${ }^{2}$ Blood-derived products are frequently used as a life-saving procedure in both routine and emergency situations that require a replacement of blood. ${ }^{3}$ Awareness of one's own blood group is essential, primarily because it is important in case an urgent transfusion is required. The awareness rate varies between different countries, ranging between $50.0 \%$ in the UK and $97.0 \%$ in Japan. ${ }^{4}$

The blood donation system in Saudi Arabia allows only healthy adults, with an age range from 18 to 65 years, to donate. ${ }^{5}$ The contribution of the young population in blood donation is essential, since they are less likely to suffer from certain conditions that would disqualify from donating. ${ }^{4}$ Moreover, the presence of health students in the teaching hospitals, with a variety of blood groups, can serve as an essential pool of potential blood donors for many reasons. These students have the benefit of easy accessibility to blood banks, are usually young and healthy, and more aware of the local needs of blood products. $^{4,6}$ The attitude of health students towards blood donation is different among countries. In Portugal, only $12.7 \%$ of health science students had ever donated blood, however, $88.0 \%$ of non-donors will donate blood if necessary. ${ }^{7}$ In Northwest Ethiopia, $16.8 \%$ of students in a university donated blood voluntarily. ${ }^{8}$ In India, $22.9 \%$ of students in a medical college had a history of blood donation, and the majority $(91.0 \%)$ were willing to donate in the future. ${ }^{6}$ In Poland, $30.2 \%$ of students were blood donors. ${ }^{4}$ In Tanzania, around $30.0 \%$ of university students donated blood, and $89.3 \%$ reported willingness to donate blood to anyone upon request. ${ }^{9}$ In Hong Kong, $49.45 \%$ of students from one university were blood donors. ${ }^{10}$ In Saudi Arabia, a study conducted between 2014 and 2015 revealed that $30.1 \%$ of healthcare students had a history of blood donation and the majority (98.0\%) reported willingness to donate blood to their relatives and nonrelatives $(90 \%){ }^{11}$

Up-to-date knowledge on the pattern of blood types and the rates of willingness of young population to donate blood is essential for national health services. Moreover, there is limited data concerning the knowledge of one's own blood group in Saudi Arabia. Hence, the objective of this study was to estimate the frequency of different $\mathrm{ABO}$ and $\mathrm{Rh}$ blood groups among health track students in a large university in the Eastern Province of Saudi Arabia, as well as to determine students' knowledge about their blood group and their willingness to donate blood.

\section{Materials and Methods Ethical Approval}

The Institutional Review Board committee at Imam Abdulrahman Bin Faisal University approved the study. The researcher obtained the written consent from all participants, and from the parents/guardians if less than 18 years old after explaining the study purpose and to reassure them that there were no negative consequences for them. Confidentiality of the data was assured. This study complied with the principles of the Declaration of Helsinki.

\section{Study Design, Setting, and Population}

This cross-sectional study included all first-year, newly accepted, health students at Imam Abdulrahman Bin Faisal University in the Eastern Province of Saudi Arabia $(\mathrm{N}=1145)$ and was conducted in the Family and Community Medicine center of the Imam Abdulrahman Bin Faisal University during August 2020 after ethical approval and informed consent was obtained.

\section{Data Collection}

The data had two components. The first part was a selfadministered questionnaire (Supplementary File). It was designed by the researchers after a review of recent literature and similar studies based on the objectives of the study. ${ }^{3,4}$ This part included questions on sociodemographic factors, self-reported $\mathrm{ABO}$ and $\mathrm{Rh}$ blood groups, participant's willingness to donate blood in the next year, and other questions that could affects the participant's knowledge on self-blood type or willingness to donate such as having chronic disease or the presence of health care workers in the family. This part was developed initially in English then double translated from English to Arabic then to English. It was tested by a pilot study among 30 students and was revised for content validity by three professional experts. 
The second part of the data was the serology results and included $\mathrm{ABO}$ and $\mathrm{Rh}$ factors tests. Blood samples were collected from participants and tested for the $\mathrm{ABO}$ and $\mathrm{Rh}$ blood groups and both were performed simultaneously with reagents (anti-A, anti-B, and anti-D). The red blood cell agglutination method was used for blood type analysis. Prior to blood extraction, the investigators approached the students and distributed the online-based self-reported questionnaires.

\section{Data Management and Analysis}

After checking for completeness and consistency, data were analyzed using IBM SPSS for Windows, version 26 (IBM Corp., Armonk, NY, USA). Good knowledge about self-blood group included participants who correctly identified their ABO blood group and/or Rh factors by comparing their answers in the survey with their serology results. Participants who incorrectly reported their ABO and/or $\mathrm{Rh}$ blood groups along with those who answered (Not sure) were included as poor knowledge. Categorical variables, were presented as percentages and frequency distribution, and the $95 \%$ confidence intervals for proportions were determined using the formula for standard error of measurement. Variables were compared using the chisquared or Fisher's exact tests. Bonferroni-corrected posthoc comparisons were conducted as appropriate. Multivariable binary logistic regression analysis was conducted to identify the independent predictors of the willingness to donate blood next year. Candidate variables were selected based on medical literature and bivariate analyses. Odds ratio (OR) with $95 \%$ confidence intervals (CI) were estimated using the full model fit and were reported in comparison with the designated reference group. The goodness-of-fit of the model was evaluated using the Omnibus and Hosmer-Lemeshow tests. The significance level was defined as $\alpha=0.05$.

\section{Results}

\section{Participants Characteristics}

The study included 1145 participants, and comprised of $54.9 \%$ female and $45.1 \%$ male students. The majority $(80.4 \%)$ of students was aged 18 years old, and $72.1 \%$ students were originally from the Eastern Province of Saudi Arabia. Only 10.5\% students had a history of chronic diseases. The hematological disorders, including glucose-6-phosphate dehydrogenase deficiency $(n=62)$ and sickle cell diseases $(n=14)$ constituted a major part of these conditions. Other reported diseases included asthma $(\mathrm{n}=17)$, type 1 diabetes mellitus $(\mathrm{n}=7)$, psoriasis $(\mathrm{n}=4)$, and eczema $(\mathrm{n}=4)$. About $40.5 \%$ of students had healthcare workers in the family (Table 1).

\section{Blood Groups of Participants}

Overall, 51.1\% of students had a blood group O making it the most frequent $\mathrm{ABO}$ blood group while the least frequent blood type was blood group $\mathrm{AB}$ (4.0\%). Furthermore, 280 (24.5\%) and 234 (20.4\%) students had blood group A and B, respectively. The majority (93.3\%) of students had Rh positive blood group.

There was no statistically significant difference in the $\mathrm{ABO}$ and $\mathrm{Rh}$ blood group types according to age and gender. However, there was a significant association between the $\mathrm{ABO}$ and $\mathrm{Rh}$ blood group types and the origin in Saudi Arabia $(P<0.05)$. While the pattern of frequency of the blood groups was similar across all the regions, it was notable that the students who were from the Southern Province had the lowest prevalence (7.5\%) of blood group B $(P=0.004)($ Table 2$)$.

\section{Awareness of Blood Group Types}

Most students had a good knowledge about their ABO (81.9\%; 95\% CI: 79.7-84.1) and $\mathrm{Rh}(81.0 \%$; 95\% CI: 78.7-83.3) blood group types. Overall, three-fourths (75.5\%; 95\% CI: 73.0-78.0) of students reported their ABO-Rh blood group correctly. Table 3 demonstrates the self-reported blood groups of the participants and their serology results. The majority of students with $\mathrm{Rh}$ positive correctly reported their $\mathrm{Rh}$ group. On the other hand, $59.8 \%$ of students who reported their Rh group as negative had a good knowledge about their Rh type. Table 4 summarizes the associations with the good knowledge about the $\mathrm{ABO}$ and $\mathrm{Rh}$ groups. For instance, male students had a higher proportion $(89.1 \%)$ of good knowledge about their ABO blood groups than their female counterparts $(76.0 \%)(P<0.001)$. Additionally, students who had a previous history of blood donation had a higher proportion of good knowledge about their $\mathrm{ABO}$ and $\mathrm{Rh}$ blood groups compared with those who had not $(90.9 \%$ and $93.9 \%$ vs $81.4 \%$ and $80.2 \%$, respectively) $(P<0.05)$. Moreover, other demographic and socioeconomic factors, including age, marital status, parental education, and having a chronic disease were not significantly associated with a good knowledge about the blood group of the student $(P>0.05)$. 
Table I Sociodemographic Characteristics of Participants

\begin{tabular}{|c|c|c|c|}
\hline \multicolumn{2}{|l|}{ Variable } & \multirow{2}{*}{$\begin{array}{c}\mathbf{N}(\%) \\
145(12.7)\end{array}$} & \multirow{2}{*}{$\begin{array}{c}{[95 \% \mathrm{Cl}]} \\
{[10.8-14.6]}\end{array}$} \\
\hline Age & 17 years & & \\
\hline & 18 years & $921(80.4)$ & [78.1-82.7] \\
\hline & 19 years & $79(6.9)$ & {$[5.4-8.4]$} \\
\hline \multirow[t]{2}{*}{ Gender } & Female & $629(54.9)$ & {$[52.0-57.8]$} \\
\hline & Male & $516(45.1)$ & {$[42.2-48.0]$} \\
\hline \multirow[t]{2}{*}{ Marital Status } & Single & II 35 (99.1) & {$[98.6-99.6)$} \\
\hline & Married & $10(0.9)$ & {$[0.4-1.4]$} \\
\hline \multirow{5}{*}{$\begin{array}{l}\text { Origin in Saudi } \\
\text { Arabia }\end{array}$} & Eastern Province & $825(72.1)$ & [69.5-74.7] \\
\hline & Central Province & $84(7.3)$ & {$[5.8-8.8]$} \\
\hline & Northern Province & $55(4.8)$ & {$[3.6-6.0]$} \\
\hline & Western Province & $6 \mathrm{I}(5.3)$ & {$[4.0-6.6]$} \\
\hline & Southern Province & $120(10.5)$ & {$[8.7-12.3]$} \\
\hline \multirow{2}{*}{$\begin{array}{l}\text { Have Chronic } \\
\text { Diseases }\end{array}$} & Yes & $120(10.5)$ & {$[8.7-12.3]$} \\
\hline & No & $1025(89.5)$ & [87.7-91.3] \\
\hline \multirow[t]{4}{*}{ Paternal Education } & Less Than Secondary School & $124(10.8)$ & {$[9.0-12.6]$} \\
\hline & Secondary School & $319(27.9)$ & {$[25.3-30.5]$} \\
\hline & Diploma or Bachelor & $569(49.7)$ & {$[46.8-52.6]$} \\
\hline & Master or Doctorate & $133(11.6)$ & {$[9.7-13.5]$} \\
\hline \multirow[t]{4}{*}{ Maternal Education } & Less Than Secondary School & $167(14.6)$ & {$[12.6-16.6]$} \\
\hline & Secondary School & $306(26.7)$ & {$[24.1-29.3]$} \\
\hline & Diploma or Bachelor & $629(54.9)$ & {$[52.0-57.8]$} \\
\hline & Master or Doctorate & $43(3.8)$ & [2.7-4.9] \\
\hline \multirow{2}{*}{$\begin{array}{l}\text { Have HCW in the } \\
\text { Family }\end{array}$} & Yes & $464(40.5)$ & [37.7-43.3] \\
\hline & No & $68 \mid(59.5)$ & {$[56.7-62.3]$} \\
\hline
\end{tabular}

Abbreviations: N, Number of participants; HCW, Healthcare workers; Cl, confidence interval.

\section{Attitudes Towards Blood Donation}

Only $66(5.8 \%)$ students reported previous experience of blood donation and most of them (83.1\%) donated only once. Moreover, only $17(1.5 \%)$ students had a history of blood transfusion. Additionally, around half (47.3\%; 95\% CI: 44.4-50.2) of participants reported a willingness to donate blood in the next 12 months.

Male students reported a higher willingness to donate blood in the next 12 months than their female counterparts (57.8\% vs $38.8 \%)(P<0.001)$. Students with a history of chronic diseases $(37.5 \%)$ were less willing to donate blood than those without (48.5\%) $(P=0.023)$. Students who had a family member in the healthcare field were slightly less willing to donate blood next year $(43.5 \%$ vs $49.9 \%)(P=$ 0.033). Moreover, a good knowledge about the blood groups was not found to be significantly associated with the willingness to donate blood $(P>0.05)$ (Table 5).

\section{Multivariable Analysis of Factors Associated with Blood Donation}

Multivariable binary logistic regression analysis was performed to identify the independent predictors of the 
Table $2 \mathrm{ABO}$ and Rh Blood Groups According to Demographic Factors

\begin{tabular}{|c|c|c|c|c|c|c|c|c|}
\hline \multicolumn{2}{|l|}{ Variable } & \multicolumn{4}{|c|}{ ABO Group } & \multirow{3}{*}{$\begin{array}{c}\text { P value } \\
0.142 \\
\end{array}$} & \multirow{3}{*}{$\begin{array}{c}\text { Rh Positive N (\%) } \\
136(93.8)\end{array}$} & \multirow{3}{*}{\begin{tabular}{|c|} 
P value \\
0.951
\end{tabular}} \\
\hline & & \multirow{2}{*}{$\begin{array}{l}\text { A N (\%) } \\
42(29.0)\end{array}$} & \multirow{2}{*}{$\begin{array}{l}\text { B N (\%) } \\
27(18.6)\end{array}$} & \multirow{2}{*}{$\begin{array}{c}\text { AB N (\%) } \\
7(4.8)\end{array}$} & \multirow{2}{*}{$\begin{array}{c}\mathbf{O} \mathbf{N}(\%) \\
69(47.6)\end{array}$} & & & \\
\hline Age & 17 years & & & & & & & \\
\hline & 18 years & $225(24.4)$ & $191(20.7)$ & $32(3.5)$ & $473(5 \mid .4)$ & & $858(93.2)$ & \\
\hline & 19 years & $13(16.5)$ & $16(20.3)$ & $7(8.9)$ & $43(54.4)$ & & $74(93.7)$ & \\
\hline \multirow[t]{2}{*}{ Gender } & Female & | 37 (2|.8) & I34 (2|.3) & $24(3.8)$ & $334(53.1)$ & \multirow[t]{2}{*}{0.120} & $591(94.0)$ & \multirow[t]{2}{*}{0.308} \\
\hline & Male & $143(27.7)$ & $100(19.4)$ & $22(4.3)$ & $25 I(48.6)$ & & $477(92.4)$ & \\
\hline \multirow[t]{5}{*}{ Origin in Saudi Arabia (Province) } & Eastern & $195(23.6)$ & $184(22.3)$ & $32(3.9)$ & $414(50.2)$ & \multirow[t]{5}{*}{0.032} & $779(94.4)$ & \multirow[t]{5}{*}{0.003} \\
\hline & Central & $21(25.0)$ & $22(26.2)$ & $4(4.8)$ & $37(44.0)$ & & $7 \mid(84.5)$ & \\
\hline & Northern & $10(18.2)$ & II (20.0) & $3(5.5)$ & $31(56.4)$ & & $54(98.2)$ & \\
\hline & Western & 17 (27.9) & $8(13.1)$ & $4(6.6)$ & $32(52.5)$ & & $55(90.2)$ & \\
\hline & Southern & $37(30.8)$ & $9(7.5)$ & $3(2.5)$ & 71 (59.2) & & $109(90.8)$ & \\
\hline
\end{tabular}

Note: $P$ values are in bold if statistically significant.

Abbreviation: N, Number of participants.

Table 3 Self-Reported and Serology Results of Participants' Blood Groups

\begin{tabular}{|c|c|c|c|c|c|}
\hline \multirow{2}{*}{\multicolumn{2}{|c|}{$\begin{array}{l}\text { Blood groups } \\
\text { ABO Groups }\end{array}$}} & \multicolumn{4}{|c|}{ Serology Result } \\
\hline & & \multirow{2}{*}{$\frac{A N(\%)}{223(89.9)}$} & \multirow{2}{*}{$\frac{\mathrm{B} N(\%)}{7(2.8)}$} & \multirow{2}{*}{$\frac{A B N(\%)}{4(1.6)}$} & \multirow{2}{*}{$\frac{\mathrm{O} N(\%)}{14(5.7)}$} \\
\hline Self- & A & & & & \\
\hline Reported & B & $3(1.6)$ & 177 (91.7) & $2(1.0)$ & II (5.7) \\
\hline & $A B$ & I (2.6) & $2(5.1)$ & 35 (89.7) & I (2.6) \\
\hline & O & $13(2.5)$ & $14(2.6)$ & $0(0)$ & $503(94.9)$ \\
\hline & Not Sure & $40(29.6)$ & $34(25.2)$ & $5(3.7)$ & $56(4 I .5)$ \\
\hline \multicolumn{2}{|c|}{ Rh Groups } & \multicolumn{2}{|c|}{ Positive N (\%) } & \multicolumn{2}{|c|}{ Negative N (\%) } \\
\hline \multirow{3}{*}{$\begin{array}{l}\text { Self- } \\
\text { Reported }\end{array}$} & Positive & \multicolumn{2}{|c|}{$875(98.1)$} & \multicolumn{2}{|c|}{$17(1.9)$} \\
\hline & Negative & \multicolumn{2}{|c|}{$35(40.2)$} & \multicolumn{2}{|c|}{$52(59.8)$} \\
\hline & Not Sure & \multicolumn{2}{|c|}{ I58 (95.2) } & \multicolumn{2}{|c|}{$8(4.8)$} \\
\hline
\end{tabular}

Note: Correctly identified blood groups are in bold.

Abbreviation: N, Number of participants.

willingness for blood donation in the next 12 months. The model revealed that male students were 1.9-times $(O R=$ 1.09; 95\% CI: $1.50-2.44)$ more likely to donate blood than their female counterparts. Additionally, the previous history of blood donation is an independent predictor $(O R=4.57$; 95\% CI: 2.33-8.94) of the willingness to donate blood next year. In contrast, having a chronic disease $(O R=$ 0.64 ; $95 \%$ CI: $0.43-0.96$ ) or having a family member in the healthcare field $(O R=0.76 ; 95 \% C I: 0.59-0.97)$ were independent predictors of the unwillingness to donate blood (Table 6).

\section{Discussion}

Awareness of one's own blood group is of great importance especially in an emergency situation that mandates blood donation. The current study determined the 
Table 4 Good Knowledge About the Self-Blood Groups in Participants

\begin{tabular}{|c|c|c|c|c|c|}
\hline \multicolumn{2}{|l|}{ Variable } & \multicolumn{4}{|c|}{ Good Knowledge About Self-Blood Group } \\
\hline & & ABO Group N (\%) & $P$ value & Rh Factor N (\%) & $P$ value \\
\hline \multirow[t]{3}{*}{ Age } & 17 years & II 8 (8I.4) & \multirow[t]{3}{*}{0.687} & $115(79.3)$ & \multirow[t]{3}{*}{0.160} \\
\hline & 18 years & $758(82.3)$ & & $754(81.9)$ & \\
\hline & 19 years & $62(78.5)$ & & $58(73.4)$ & \\
\hline \multirow[t]{2}{*}{ Gender } & Female & $478(76.0)$ & \multirow[t]{2}{*}{$<0.001$} & $478(76.0)$ & \multirow[t]{2}{*}{$<0.001$} \\
\hline & Male & $460(89.1)$ & & $449(87.0)$ & \\
\hline \multirow[t]{2}{*}{ Marital Status } & Single & $931(82.0)$ & \multirow[t]{2}{*}{0.400} & $919(81.0)$ & \multirow[t]{2}{*}{1.000} \\
\hline & Married & $7(70.0)$ & & $8(80.0)$ & \\
\hline \multirow[t]{4}{*}{ Paternal Education } & Less Than Secondary School & $100(80.6)$ & \multirow[t]{4}{*}{0.531} & $95(76.6)$ & \multirow[t]{4}{*}{0.591} \\
\hline & Secondary School & $254(79.6)$ & & $258(80.9)$ & \\
\hline & Diploma or Bachelor & $475(83.5)$ & & $464(81.5)$ & \\
\hline & Master or Doctorate & $109(82.0)$ & & $110(82.7)$ & \\
\hline \multirow{4}{*}{$\begin{array}{l}\text { Maternal } \\
\text { Education }\end{array}$} & Less Than Secondary School & $138(82.6)$ & \multirow[t]{4}{*}{0.712} & $136(8 \mid .4)$ & \multirow[t]{4}{*}{0.850} \\
\hline & Secondary School & $244(79.7)$ & & $25 I(82.0)$ & \\
\hline & Diploma or Bachelor & $520(82.7)$ & & $507(80.6)$ & \\
\hline & Master or Doctorate & $36(83.7)$ & & $33(76.7)$ & \\
\hline \multirow[t]{2}{*}{ Chronic Disease } & Yes & $100(83.3)$ & \multirow[t]{2}{*}{$0.67 I$} & $97(80.8)$ & \multirow[t]{2}{*}{0.970} \\
\hline & No & $838(81.8)$ & & $830(81.0)$ & \\
\hline \multirow[t]{2}{*}{$\mathrm{HCW}$ in Family } & Yes & $385(83.0)$ & \multirow[t]{2}{*}{0.445} & $393(84.7)$ & \multirow[t]{2}{*}{0.008} \\
\hline & No & $553(8 \mid .2)$ & & $534(78.4)$ & \\
\hline \multirow[t]{2}{*}{ Donated Blood } & Yes & $60(90.9)$ & \multirow[t]{2}{*}{0.049} & $62(93.9)$ & \multirow[t]{2}{*}{0.006} \\
\hline & No & $878(8 I .4)$ & & $865(80.2)$ & \\
\hline \multirow[t]{2}{*}{ Received Blood } & Yes & $13(76.5)$ & \multirow[t]{2}{*}{0.528} & $12(70.6)$ & \multirow[t]{2}{*}{0.344} \\
\hline & No & $925(82.0)$ & & $915(81.1)$ & \\
\hline \multirow[t]{2}{*}{ Had Surgery } & Yes & $187(83.1)$ & \multirow[t]{2}{*}{0.605} & $187(83.1)$ & \multirow[t]{2}{*}{0.359} \\
\hline & No & $75 I(8 I .6)$ & & $740(80.4)$ & \\
\hline
\end{tabular}

Note: $P$ values are in bold if statistically significant.

Abbreviations: N, Number of participants; HCW, Healthcare workers.

frequencies of $\mathrm{ABO}$ and $\mathrm{Rh}$ blood groups among first-year health students in a large university in the largest Province of Saudi Arabia, where there is a lack of data on this subject. Moreover, to the best of our knowledge, there have been no previous studies in Saudi Arabia concerning knowledge about one's own blood group.

This study showed that the most frequent blood type is O (51.1\%), followed by blood group A $(24.5 \%)$ and
$\mathrm{B}(20.4 \%)$, and the least frequent is type $\mathrm{AB}(4.0 \%)$. Additionally, the majority (93.3\%) of students had $\mathrm{Rh}$ positive blood group. This is consistent with studies conducted in different countries, and is especially similar to the distribution of $\mathrm{ABO}$ and $\mathrm{Rh}$ blood groups in Tanzania. ${ }^{12}$ Moreover, a similar pattern was reported in studies from Ethiopia, Kenya, Mauritania, Nigeria, Uganda, and among blood and stem cell donors in Saudi 
Table 5 Willingness to Donate Blood Next Year in Participants

\begin{tabular}{|c|c|c|c|c|c|c|}
\hline \multirow{2}{*}{\multicolumn{4}{|c|}{ Variable }} & \multicolumn{3}{|c|}{ Willingness to Donate Blood } \\
\hline & & & & $\mathbf{N}$ & (\%) & $P$ value \\
\hline \multirow[t]{3}{*}{ Age } & \multicolumn{3}{|c|}{17 years } & 72 & $(49.7)$ & \multirow[t]{3}{*}{0.152} \\
\hline & \multicolumn{3}{|c|}{18 years } & 425 & $(46.1)$ & \\
\hline & \multicolumn{3}{|c|}{19 years } & 45 & $(57.0)$ & \\
\hline \multirow[t]{2}{*}{ Gender } & \multicolumn{3}{|c|}{ Female } & 244 & $(38.8)$ & \multirow[t]{2}{*}{$<0.001$} \\
\hline & \multicolumn{3}{|c|}{ Male } & 298 & $(57.8)$ & \\
\hline \multirow[t]{2}{*}{ Marital Status } & \multicolumn{3}{|c|}{ Single } & 536 & $(47.2)$ & \multirow[t]{2}{*}{0.531} \\
\hline & \multicolumn{3}{|c|}{ Married } & 6 & $(60.0)$ & \\
\hline \multirow[t]{4}{*}{ Paternal Education } & \multicolumn{3}{|c|}{$\begin{array}{l}\text { Less Than Secondary } \\
\text { School }\end{array}$} & 63 & $(50.8)$ & \multirow[t]{4}{*}{0.341} \\
\hline & \multicolumn{3}{|c|}{ Secondary School } & 146 & $(45.8)$ & \\
\hline & \multicolumn{3}{|c|}{ Diploma or Bachelor } & 278 & $(48.9)$ & \\
\hline & \multicolumn{3}{|c|}{ Master or Doctorate } & 55 & $(47.3)$ & \\
\hline \multirow[t]{4}{*}{ Maternal Education } & \multicolumn{3}{|c|}{$\begin{array}{l}\text { Less Than Secondary } \\
\text { School }\end{array}$} & 89 & $(53.3)$ & \multirow[t]{4}{*}{0.121} \\
\hline & \multicolumn{3}{|c|}{ Secondary School } & 135 & $(44.1)$ & \\
\hline & \multicolumn{3}{|c|}{ Diploma or Bachelor } & 293 & $(46.6)$ & \\
\hline & \multicolumn{3}{|c|}{ Master or Doctorate } & 25 & $(58.1)$ & \\
\hline \multirow[t]{2}{*}{ Chronic Diseases } & \multicolumn{3}{|l|}{ Yes } & 45 & $(37.5)$ & \multirow[t]{2}{*}{0.023} \\
\hline & No & & & 497 & $(48.5)$ & \\
\hline $\mathrm{HCW}$ in Family & Yes & & & 202 & $(43.5)$ & 0.033 \\
\hline & No & & & 340 & $(49.9)$ & \\
\hline Donated Blood & Yes & & & 55 & $(83.3)$ & $<0.001$ \\
\hline & No & & & 487 & $(45.1)$ & \\
\hline Received Blood & Yes & & & 9 & $(52.9)$ & $0.64 I$ \\
\hline & No & & & 533 & $(47.3)$ & \\
\hline Good Knowledge ab & & $A B O$ & Yes & 441 & $(47.0)$ & 0.643 \\
\hline Groups & & & No & 101 & $(48.8)$ & \\
\hline & & $\mathrm{Rh}$ & Yes & 446 & $(48.1)$ & 0.278 \\
\hline & & & No & 96 & $(44.0)$ & \\
\hline & & Both & Yes & 414 & $(47.9)$ & 0.490 \\
\hline & & & No & 128 & $(45.6)$ & \\
\hline
\end{tabular}

Note: $P$ values are in bold if statistically significant.

Abbreviations: N, Number of participants; HCW, Healthcare workers. 
Table 6 Multivariable Regression of Factors Associated with Willingness to Donate Next Year

\begin{tabular}{|c|c|c|c|c|c|c|c|}
\hline \multicolumn{2}{|c|}{ Variables } & \multicolumn{3}{|c|}{ Univariable Logistic Regression } & \multicolumn{3}{|c|}{ Multivariable Logistic Regression } \\
\hline & & \multirow{2}{*}{$\begin{array}{l}\text { OR } \\
1.0\end{array}$} & {$[95 \% \mathrm{Cl}]$} & $P$ value & \multirow{2}{*}{$\begin{array}{c}\text { OR } \\
1.0\end{array}$} & {$[95 \% \mathrm{Cl}]$} & $P$ value \\
\hline Age & 17 years & & \multicolumn{2}{|c|}{ Reference Group } & & \multicolumn{2}{|c|}{ Reference Group } \\
\hline & 18 years & 0.87 & {$[0.6 \mathrm{I}-1.23]$} & 0.431 & 0.82 & {$[0.57-1.17]$} & 0.268 \\
\hline & 19 years & 1.34 & {$[0.77-2.33]$} & 0.296 & 1.09 & {$[0.62-1.94]$} & 0.758 \\
\hline \multicolumn{2}{|c|}{ Male Gender } & 2.16 & {$[1.70-2.73]$} & $<0.001$ & 1.91 & {$[1.50-2.44]$} & $<0.001$ \\
\hline \multicolumn{2}{|c|}{ Have Chronic Diseases } & 0.64 & {$[0.43-0.94]$} & 0.023 & 0.64 & {$[0.43-0.96]$} & 0.031 \\
\hline \multicolumn{2}{|c|}{ Donated Blood Previously } & 6.08 & {$[3.15-11.74]$} & $<0.001$ & 4.57 & {$[2.33-8.94]$} & $<0.001$ \\
\hline \multicolumn{2}{|c|}{ Have HCW in the Family } & 0.77 & {$[0.6 \mathrm{I}-0.98]$} & 0.034 & 0.76 & {$[0.59-0.97]$} & 0.026 \\
\hline
\end{tabular}

Note: $P$ values are in bold if statistically significant.

Abbreviations: OR, odds ratio; $\mathrm{Cl}$, confidence interval; $\mathrm{HCW}$, healthcare workers.

Arabia in which blood group $\mathrm{O}$ was the predominant group and $\mathrm{AB}$ was the least prevalent. ${ }^{2,12,13}$ Demand for blood products is high, and blood banks need up-to-date information regarding the frequency of blood groups in the region to ensure sufficient supply, especially for the most required blood types. ${ }^{12}$ Our study found a significant association between the $\mathrm{ABO}$ and $\mathrm{Rh}$ blood group types and participant's origin in Saudi Arabia. While the pattern of frequency of the blood groups was similar across all the regions, students from the Southern Province had the lowest prevalence $(7.5 \%)$ of blood group B. It has been previously described that societies practicing endogamy tend to be genetically isolated. For instance, genetic studies among several endogamous populations in Bihar, India, revealed that these populations have less gene diversity and thus have less variability in $\mathrm{ABO}$ and $\mathrm{Rh}$ blood groups. ${ }^{14}$ Thus, the cultural tradition of endogamy may contribute to the observed pattern of blood group distribution in the Southern region.

When we compared students' answers to questions about their blood group with their sample results, most students correctly reported their $\mathrm{ABO}(81.9 \%)$ and $\mathrm{Rh}$ $(81.0 \%)$ blood group types. Moreover, three-fourths (75.5\%) of students reported their $\mathrm{ABO}$ and $\mathrm{Rh}$ blood groups correctly. In line with these findings, a study among 1121 students with different health specialties in Poland found that $86.8 \%$ of students were aware of their blood group. ${ }^{4}$ Slightly higher than our findings, a study on 235 medical students in North India found that $95.7 \%$ of students were aware of their blood types. However, the data was collected through a self-reported survey rather than comparing students' answers with a more objective tool. ${ }^{6}$ Another study in Nigeria among 155 undergraduate medical and dental students showed that less than half of them (43.9\%) knew their blood groups. ${ }^{15}$ Although the small sample size was a major limitation in that study, their finding of a significant association between a history of blood donation and student's awareness of their blood groups was in line with our study. ${ }^{15}$ This study showed that male students had a higher proportion of knowledge about their $\mathrm{ABO}$ and $\mathrm{Rh}$ blood groups than their female counterparts. This observation could be attributed to some regulations in the Kingdom where until very recently, females were not allowed to drive. Information on ABO and $\mathrm{Rh}$ factors are reported in the driver license. Therefore, this discrepancy in knowledge between males and females may be eliminated in the next few years with the growing number of females drivers in the country.

The relatively small number of students with a history of donation may be attributed to the policy implemented by Saudi Arabia's Ministry of Health where donation is not permitted for individuals below 18 years of age, and our population's age ranged between 17 and 19 years old.

While most of blood donors in this study (83.1\%) reported donating blood only once in their lifetime, those who donated were more likely to do it again over the next year. These results corroborate the findings of Huis In ' $\mathrm{T}$ Veld et al in which blood shortages were more likely to be alleviated by previous donors. ${ }^{16}$

Willingness to donate blood has been a question of interest in similar studies with a remarkably wide range of results. A survey conducted in Kilimanjaro, Tanzania, reported that $89.3 \%$ of their university students' sample $(\mathrm{n}=422)$ were willing to donate blood to anyone 
voluntarily, and $94.5 \%$ were willing to donate blood to their relatives. ${ }^{9}$ In our study, we found that about half $(47.3 \%)$ of participants reported a willingness to donate blood in the next 12 months.

Consistent with previous research, we found that male students report more willingness to donate blood than their female counterparts. ${ }^{9,12}$ Additionally, this finding was documented in a Saudi study in which females constituted less than $5.0 \%$ of blood donors. ${ }^{17}$ Bani and Giussani have described in a literature review how gender appeared to play a critical role in the motivation to donate blood. They reported that females seemed more guarded about repeated blood donations and were more fearful of adverse reactions making them less frequent blood donors. ${ }^{18}$ Another study that surveyed 469 female students revealed that $89.3 \%$ of them had never donated blood. When asked about reasons, they cited fear, accessibility issues to donation sites, and not having time to donate. ${ }^{19}$ These observations highlight the need to raise awareness among females about the safety of giving blood and breaking the barriers to blood donation.

In this study, we found that students with a reported history of chronic diseases were less willing to donate blood in the next 12 months than those without. It is not precisely clear why, however, most of the reported chronic diseases were hematologic conditions such as sickle cell disease, which may explain why these students seem to be less willing to donate blood. Another possible explanation for this might be linked to some blood donors' safety concerns reported in a large cross-sectional study in the European Union. ${ }^{16}$ However, we did not assess the students' knowledge about the contraindications of a blood donation. Nonetheless, misconceptions and myths around blood donation and blood transfusion are not uncommon. $^{3,11,20}$

Contrary to expectations, students with a family member in the healthcare field were slightly less willing to donate blood. Our analysis showed that this was an independent predictor for the unwillingness for blood donation. It is known that blood donation is remarkably safe, and the perceived risk for a transfusion has not been associated with objective knowledge. ${ }^{21,22}$ However, experimental studies to examine the impact of message cueing and framing on young adults indicated that people's perception might be altered by how the information is presented. For instance, Farrell et al suggested that presenting blood donation/transfusion risk information as a positive frame, compared with either a mixed or negative frame, resulted in people voicing more confidence on the safety of blood donation/transfusion. ${ }^{23}$ Likewise, it could be argued that learning more about the potential risks, or in a negative frame, from a relative healthcare worker may adversely impact the person's willingness to donate blood. There is limited data available to explain this observation. Hence, this question remains unanswered at present.

This study has some limitations; it was cross-sectional, and we cannot establish the temporal relationship between the associated factors we observed with a willingness to blood donation among the population in this study. Data on the history of previous blood donation and its frequency depend on self-reported information by the students and was not verified with any registry or medical reports. Therefore, recall bias could not be excluded. Moreover, involving a limited age range is another limitation in this study.

\section{Conclusion}

This study provides epidemiological information about the blood groups' distribution, knowledge about self-blood groups, blood donation willingness and the associated characteristics among the first-year health students in a large university in the Eastern Province of Saudi Arabia. ABO blood group $\mathrm{O}$ and positive $\mathrm{Rh}$ type were the most frequent blood groups, and most students knew their blood groups. Additionally, about half of students were willing to donate blood during the next year. Encouraging the young population, especially females, to participate in blood donation is important. Moreover, similar studies across the Kingdom are recommended.

\section{Acknowledgments}

The authors want to acknowledge the following medical interns who participated in the data collection process: Ammar Saleem Bukhamsin, Abdullah Zuhair Al-Sahow, Kawthar Sayed Hameed Ebrahim, Zakiya Sayed Khalaf Shubbar, Abdullah Mansour Alomran, Rana Mohammed Almaharfi, Ali Mustafa Alhabrti, Hassan Mohammed AlHammadi, Ahad Yasir Shaikh, Bayader Waleed AlHamad, Abdullah Mansour Alomran, Sarah Adel Aljishi, Asma Aedh Saad Alqarni, Ghadah Fahad AlFaraj, Raghad Fahad AlFaraj, Danah Mohammed Almoaibed, and Nouf Ibrahim Albrahim. All these individuals have provided permission to be acknowledged.

\section{Disclosure}

The authors report no conflicts of interest in this work. 


\section{References}

1. Liu J, Zhang S, Wang Q, Shen H, Zhang Y, Liu M. Frequencies and ethnic distribution of $\mathrm{ABO}$ and $\mathrm{RhD}$ blood groups in China: a Population-Based Cross-Sectional Study. BMJ Open. 2017;7(12): e018476. doi:10.1136/bmjopen-2017-018476

2. Alzahrani M, Jawdat D, Alaskar A, Cereb N, Hajeer AH. ABO and $\mathrm{Rh}$ blood group genotypes in a cohort of Saudi stem cell donors. Int J Immunogenet. 2018;45(2):63-64. doi:10.1111/iji.12354

3. Urgesa K, Hassen N, Seyoum A. Knowledge, attitude, and practice regarding voluntary blood donation among adult residents of Harar Town, Eastern Ethiopia: a Community-Based Study. J Blood Med. 2017;8:13-20. doi:10.2147/JBM.S121460

4. Ciepiela O, Jaworska A, Łacheta D, Falkowska N, Popko K, Demkow U. Awareness of blood group and blood donation among medical students. Transfus Apher Sci. 2017;56(6):858-864. doi:10.1016/j.transci.2017.10.002

5. Ministry of Health, Saudi Arabia. Blood donation. Facts and guidelines [Internet]; 2014. Available from: https://www.moh.gov.sa/en/ HealthAwareness/EducationalContent/Blog/1435/Pages/Artical2014-06-08.aspx. Accessed June 30, 2021.

6. Chauhan R, Kumar R, Thakur S. A study to assess the knowledge, attitude, and practices about blood donation among medical students of a medical college in North India. J Fam Med Prim Care. 2018;7 (4):693-697. doi:10.4103/jfmpc.jfmpc_54_17.

7. Gomes MJ, Nogueira AJ, Antão C, Teixeira C. Motivations and attitudes towards the act of blood donation among undergraduate health science students. Transfus Apher Sci. 2019;58(2):147-151. doi:10.1016/j.transci.2018.12.018

8. Talie E, Wondiye H, Kassie N, Gutema H. Voluntary blood donation among bahir dar university students: application of integrated behavioral model, Bahir Dar, Northwest Ethiopia, 2020. J Blood Med. 2020;11:429-437. doi:10.2147/JBM.S277411

9. Elias E, Mauka W, Philemon RN, Damian DJ, Mahande MJ, Msuya SE. Knowledge, attitudes, practices, and factors associated with voluntary blood donation among university students in Kilimanjaro, Tanzania. J Blood Transfus. 2016;2016:8546803. doi:10.1155/2016/8546803

10. Suen LKP, Siu JY, Lee YM, Chan EA. Knowledge level and motivation of Hong Kong young adults towards blood donation: a cross-sectional survey. BMJ Open. 2020;10(1):e031865. doi:10.1136/bmjopen-2019-031865.

11. Alsalmi MA, Almalki HM, Alghamdi AA, Aljasir BA. Knowledge, attitude and practice of blood donation among health professions students in Saudi Arabia; a Cross-Sectional Study. J Fam Med Prim Care. 2019;8(7):2322-2327. doi:10.4103/jfmpc.jfmpc_415_19
12. Jahanpour O, Pyuza JJ, Ntiyakunze EO, Mremi A, Shao ER. ABO and Rhesus blood group distribution and frequency among blood donors at Kilimanjaro Christian Medical Center, Moshi, Tanzania. BMC Res Notes. 2017;10(1):738. doi:10.1186/s13104-017-3037-3

13. Bashwari LA, Al-Mulhim AA, Ahmad MS, Ahmed MA. Frequency of ABO blood groups in the eastern region of Saudi Arabia. Saudi Med J. 2001;22(11):1008-1012.

14. Pandey BN, Das PK, Husain S, Anwer MR, Jha AK. Genetic studies among seven endogamous populations of the Koshi Zone, Bihar (India). Anthropol Anz. 2003;61(3):269-274. doi:10.1127/anthranz/ $61 / 2003 / 269$

15. Akingbola TS, Yuguda S, Akinyemi OO, Olomu S. Awareness and distribution of $\mathrm{ABO}$, Rhesus blood groups and haemoglobin phenotypes among medical undergraduates in a Nigerian university. Afr J Med Med Sci. 2016;45(3):275-280.

16. Huis In 'T Veld EMJ, de Kort W, Merz EM. Determinants of blood donation willingness in the European Union: a cross-country perspective on perceived transfusion safety, concerns, and incentives. Transfusion. 2019;59(4):1273-1282. doi:10.1111/trf.15209

17. Al-Johar AW, Al-Saud A, Abalkhail Y, et al. Why do-Saudi women refrain donating their blood?--a study on the attitude, belief and motivation of Saudi female university students towards blood donation. Clin Lab. 2016;62(5):771-779. doi:10.7754/Clin. Lab.2015.150718

18. Bani M, Giussani B. Gender differences in giving blood: a review of the literature. Blood Transfus. 2010;8(4):278-287. doi:10.2450/ 2010.0156-09

19. Tariq S, Tariq S, Jawed S, Tariq S. Knowledge and attitude of blood donation among female medical students in Faisalabad. $J$ Pak Med Assoc. 2018;68(1):65-70.

20. Alfouzan N. Knowledge, attitudes, and motivations towards blood donation among King Abdulaziz Medical City population. Int J Family Med. 2014;2014:539670. doi:10.1155/2014/539670

21. Lowe KC, Ferguson E. Benefit and risk perceptions in transfusion medicine: blood and blood substitutes. J Intern Med. 2003;253 (5):498-507. doi:10.1046/j.1365-2796.2003.01149.x

22. Ferguson E, Farrell K, Lowe KC, James V. Perception of risk of blood transfusion: knowledge, group membership and perceived control. Transfus Med. 2001;11(2):129-135. doi:10.1046/j.13653148.2001.00295-4.x

23. Farrell K, Ferguson E, James V, Lowe KC. Confidence in the safety of blood for transfusion: the effect of message framing. Transfusion. 2001;41(11):1335-1340. doi:10.1046/j.1537-2995.2001.41111335.x
Journal of Blood Medicine

\section{Publish your work in this journal}

The Journal of Blood Medicine is an international, peer-reviewed, open access, online journal publishing laboratory, experimental and clinical aspects of all aspect pertaining to blood based medicine including but not limited to: Transfusion Medicine; Blood collection, Donor issues, Transmittable diseases, and Blood banking logistics; Immunohematology; Artificial and alternative blood based therapeutics; Hematology; Biotechnology/nanotechnology of blood related medicine; Legal aspects of blood medicine; Historical perspectives. The manuscript management system is completely online and includes a very quick and fair peer-review system. Visit http://www.dovepress.com/testimonials.php to read real quotes from published authors. 